\title{
SEDIMENTOLOGICAL AND GEOCHEMICAL ANALYSIS OF MIOCENE DEPOSITS IN MOSCHOPOTAMOS AREA, IN THE WESTERN PART OF AXIOS-THERMAIKOS BASIN, NW GREECE
}

\author{
Savva V. ${ }^{1}$, Tserolas P. ${ }^{1}$, Maravelis A. ${ }^{2}$, Bourli N. ${ }^{1}$ and Zelilidis A. ${ }^{1}$ \\ ${ }^{1}$ Department of Geology, University of Patras, Patra, 26110, Greece \\ ${ }^{2}$ School of Environmental and Life Sciences, University of Newcastle, Callaghan 2308 NSW, \\ Australia
}

\begin{abstract}
A total of 27 samples of the Moschopotamos area lignite-bearing strata were studied in regard of their geochemical and sedimentary characteristics. Organic content and calcium carbonate evaluation, sieve analysis and micropaleontological observations were used and combined to investigate the paleoenvironment and the depositional conditions of the study area. TOC analysis showed that organic matter values range from $0.07 \%$ up to $13.42 \%$ with an average of $\sim 3.26 \%$. The high average of organic carbon content indicates a promising basis for the sediments' source rock potential, inquiring further and thorough examination. $\mathrm{CaCO}_{3}$ measurements present a range between $4 \%$ and $23 \%$. A comparison between $\mathrm{TOC}_{-} \mathrm{CaCO}_{3}$ content throughout the stratigraphic column presented certain synchronous and inverse trends, due to alterations of the depositional conditions. This study provides new insights for the understanding of the broader Axios-Thermaikos basin, and depositional conditions in the North Aegean area.
\end{abstract}

Keywords: $\mathrm{TOC}, \mathrm{CaCO}_{3}$, grain-size analysis, Moschopotamos, North Aegean.

\section{Пєрі́ $\eta \psi \eta$}

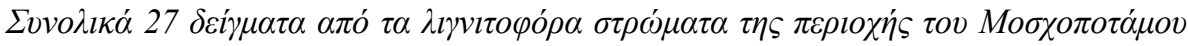

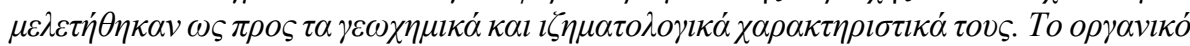

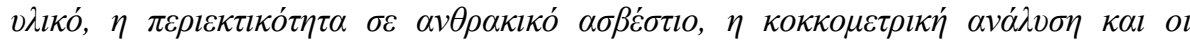

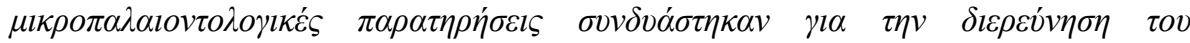

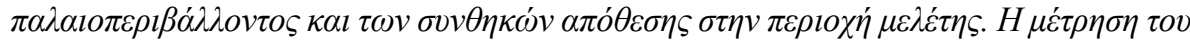

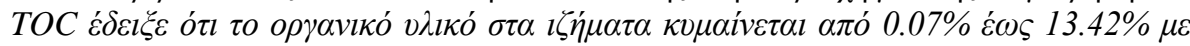

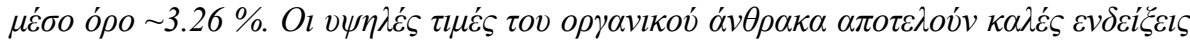

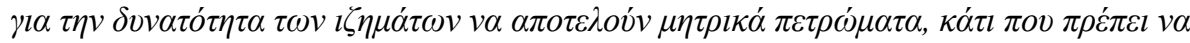

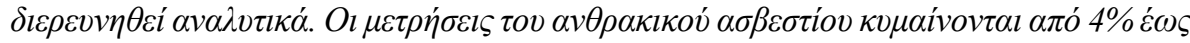

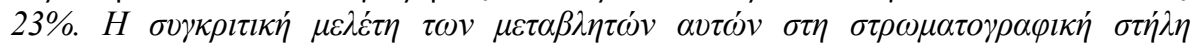

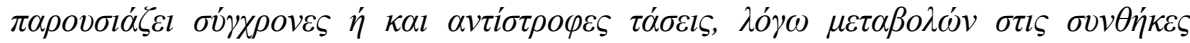

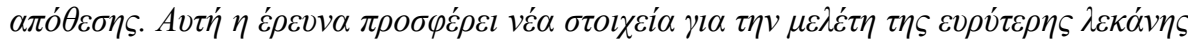

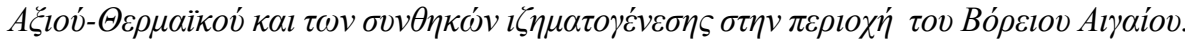

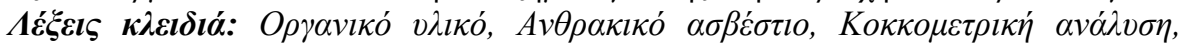

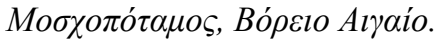




\section{Introduction - Geological Setting}

The Moschopotamos section is the W-SW margin of the broad Axios-Thermaikos fault-bounded sedimentary basin (Fig. 1). The Axios-Thermaikos subduction is part of the North Aegean area, a complex region with distinct depocenters extending to Bulgarian and Turkish domains (Maravelis and Zelilidis, 2013; Maravelis et al., 2015).

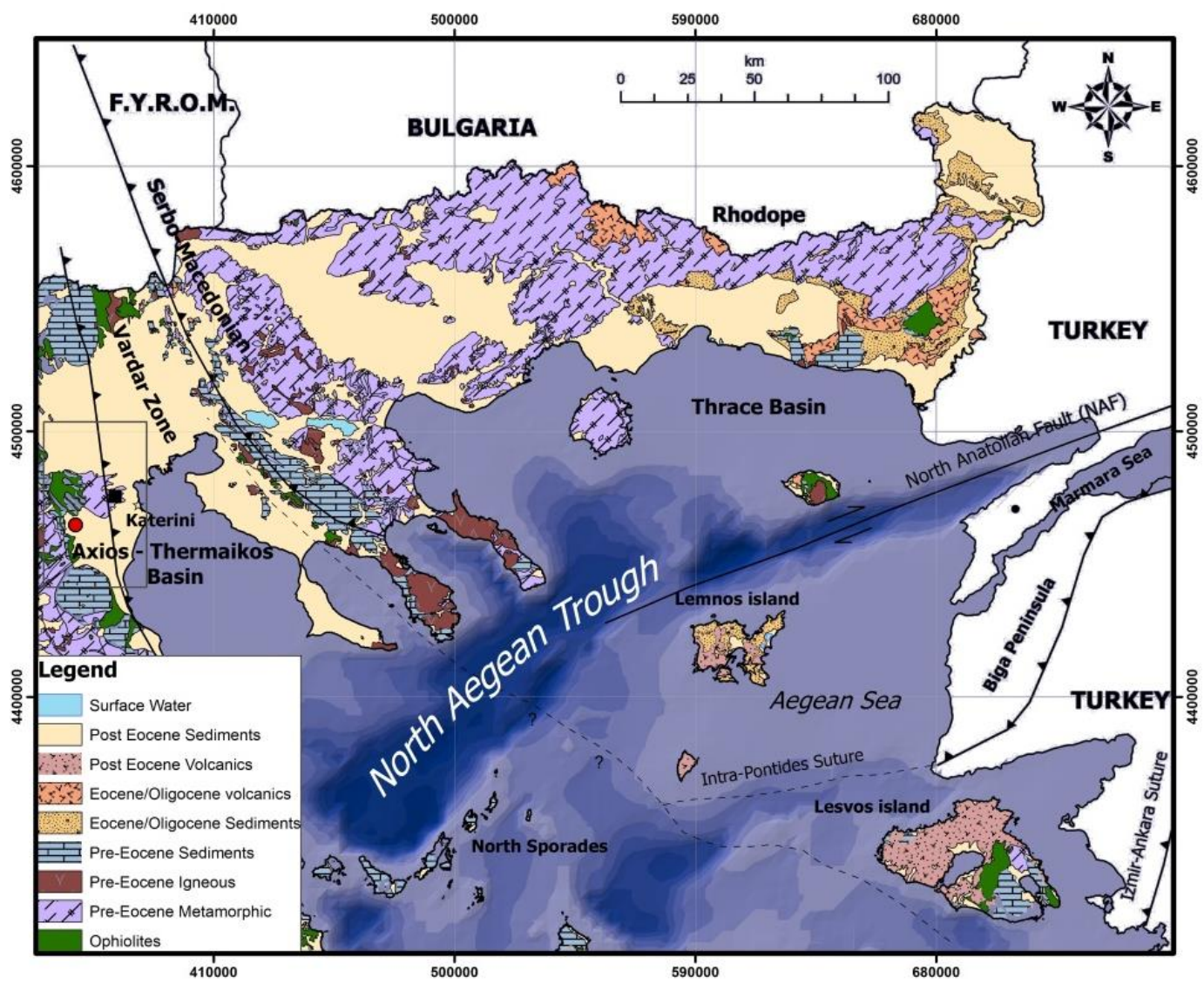

Figure 1 - Geological Map of the North Aegean with major tectonic elements (modified by Maravelis et al., 2015).

The North Aegean Trough (NAT) is a 300km long, ENE-WSW trending narrow graben system, characterized by extensional tectonics and strike-slip faults (Maravelis et al., 2015; Lycousis, 2002) and is located along the Tethys Ocean [Vardar (Axios) Zone and Intra-Pontide Suture in Turkey] (Mountrakis, 2006). It was formed during late Oligocene - middle Miocene mainly as a result of collisional processes between Eurasia and Apulia plates combined by the westward progradation of the North Anatolia Fault (NAF) (Maravelis et al., 2015; Brooks and Ferentinos, 1980). The AxiosThermaikos basin is the western depocenter of the broad North Aegean continental margin. It overlies mainly the Vardar (Axios) Zone, a fault defined crystalline massif, part of the Internal Hellenides and trending NNW-SSE through F.Y.R.O.M. and Bulgaria to the North, reaching North Crete and Western Turkey (Izmir-Ankara Zone) (Brooks and Ferentinos, 1980). The basin overlies the eastern margin of the Pelagonian zone and reaches up to North Sporades basin (Brooks and Ferentinos, 1980).

As a result of the extensive subsidence, controlled by the complex back-arc extensional regime of the area, the basin presents an early Miocene to Quaternary sediment accumulation and can be 
divided in the deeper parts (Thermaikos Gulf) and the shallower to terrestrial parts (Katerini and westwards to Moschopotamos area). The westward margins of the basin are characterized by the presence of lignite bearing strata which have been thoroughly, albeit exclusively studied (e.g. Faugeres et al., 1976; Benda and Steffens, 1981; Kotis et al., 1989; Kalkreuth et al., 1991).

The sediment flow is generally derived from the north and west further feeds the Thermaikos subbasin. Most of the studies present a terrestrial to lacustrine paleoenviroment for the sediments. Present day outcrops are surrounded by the crystalline metamorphic basement (Fig. 2) but several areas are exposed due to the economical significance of the Moschopotamos lignite deposits (e.g. Meliadi mine). A detailed stratigraphy and sampling in the Moschopotamos area took place, investigating several geochemical and sedimentological parameters in order to further understand the depositional mechanisms and conditions. This is study is part of a broad research in the North Aegean region and specifically the Axios-Thermaikos basin.

\section{Stratigraphy}

The aggregate thickness of the Neogene accumulation has been estimated of approx. 1000m (Kalkreuth et al., 1991). The stratigraphic column of the basin can be divided in three major series (Fig. 3). Older studies (Benda and Steffens, 1981; Kotis et al., 1989; Kalkreuth et al., 1991) have suggested a terrestrial to low salinity depositional environment. The lower part of the basin, of $\sim 400 \mathrm{~m}$ thickness, is exposed in the northern margin of the study area due to extensive erosion of the overlying strata. It mainly comprises of conglomerates of terrestrial origin and sandstone beds (reaching up to $10 \mathrm{~m}$ thickness). Silt and sandy clay beds are also present. The middle part, of an overall thickness of $>200 \mathrm{~m}$, is the lignite bearing part of the basin, where the present study is focused. The age of the coal beds have been identified in Lower Miocene by palynological measurements (Benda and Steffens, 1981) and where deposited in a swamp to limnic lower delta environment (Kalkreuth et al., 1991). The coal beds are followed by unconsolidated sandstones, silt and clay. The upper part comprises of sandstone and clay beds and is of Late Miocene age (Pontian). Lignite beds also occur, but of no economic importance (Kalkreuth et al., 1991).

Field investigations and sampling focused in the middle part of the basin. The strata outcrop in the broad Meliadi area (Fig. 2). The strata can be further divided in three sub-sections, in regard of their sedimentological characteristics (Fig. 3): The lower part, comprising of sandstone beds with greyish clay (type A) alterations. The middle part, comprising of the lignite beds $(<1 \mathrm{~m})$ within greenish clays (type B) and sandy clays. The upper part, with sand beds of increasing thickness moving upwards and thinner clay beds, marking the transition to the upper series of the stratigraphic column. Sampling was evenly distributed throughout the column, while lignite samples were also collected. 


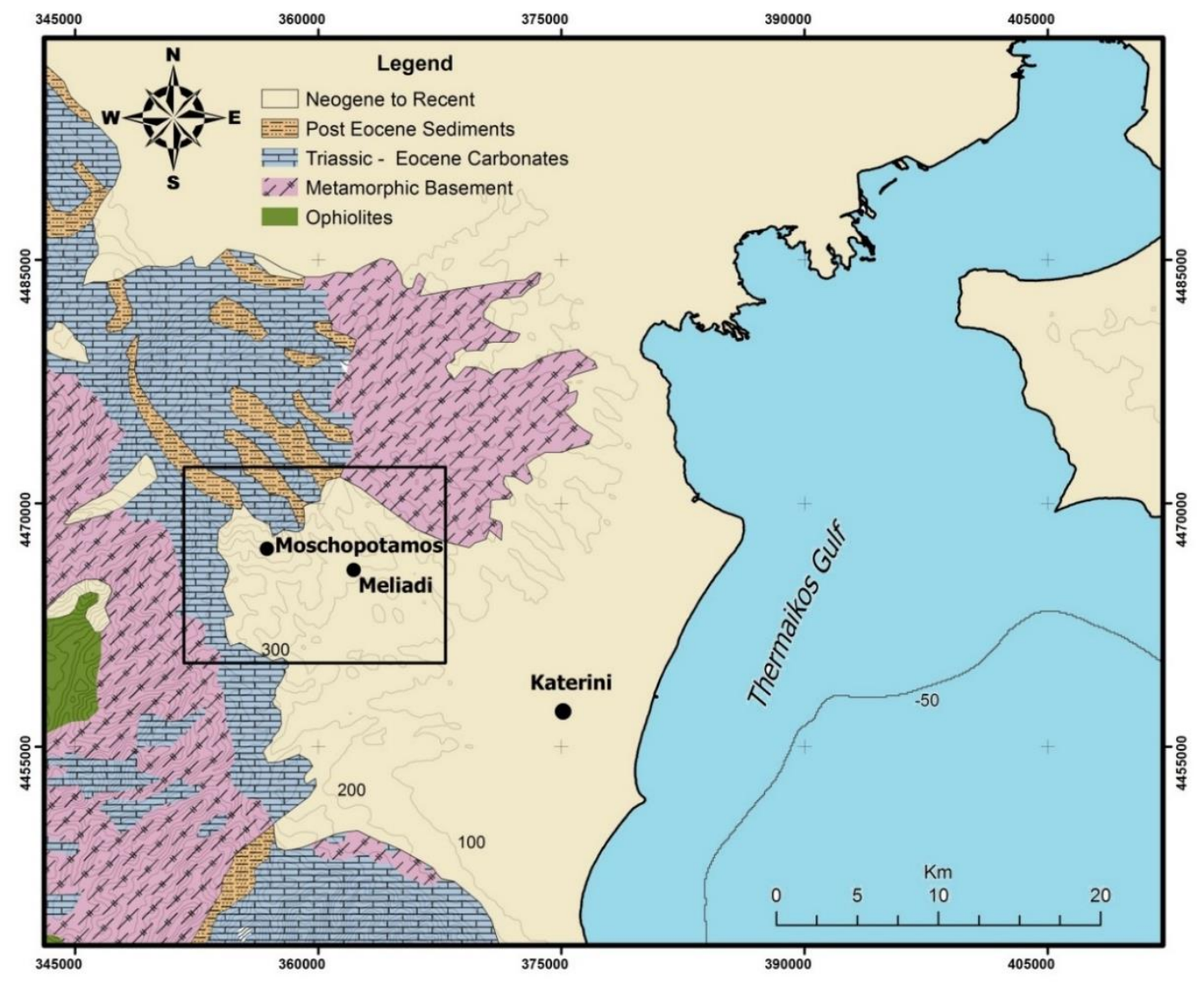

Figure 2 - Generalized geological map of the study area (modified by IGME, 1971)

\section{Laboratory Results - Geochemical and sedimentological characteristics}

\subsection{Organic matter content}

Quantitative determination of organic carbon in the sample based on the oxidation of organic carbon content in the samples was performed with the titration method (Gaudette et al., 1974). The studied samples present a highly variable TOC content (Fig. 4), ranging from $0.07 \%$ up to $13.42 \%$. The highest TOC content values were found in the middle, coal bearing part of the sampling site (samples $\mathrm{K} 14$ to $\mathrm{K} 24$ ) were the high TOC content results to an average of 5.06\%. The lower part (K1 to K13) presents a similar distribution of the TOC values, ranging from $0.4 \%$ to $1.6 \%$, with the exception of sample K12 which presents very high TOC content (11.88\%). The upper part (K25 to K27) present TOC values ranging from $3.4 \%$ to $6.0 \%$. 


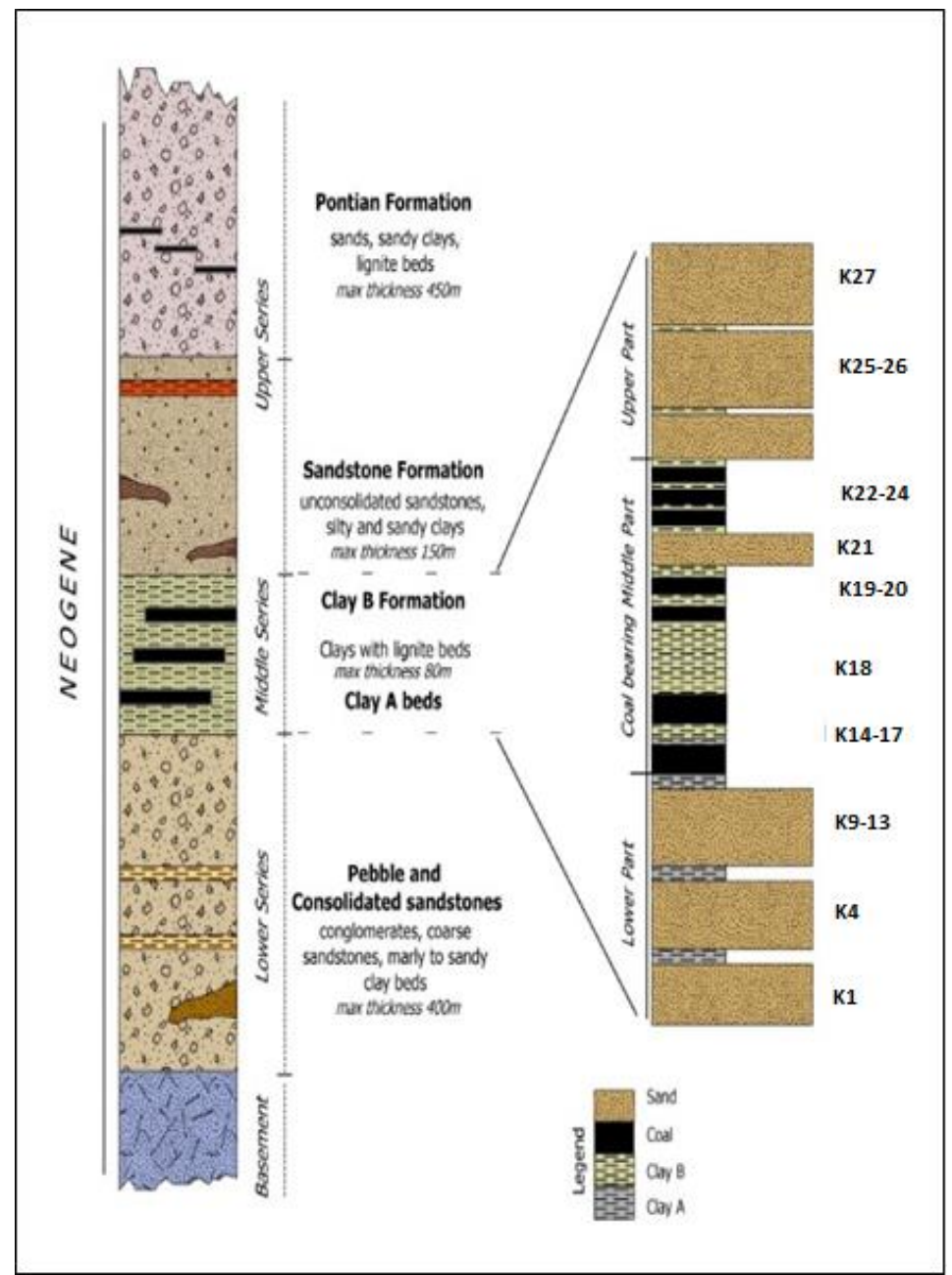

Figure 3 - Stratigraphic column of the study area (modified from Kalkreuth et al., 1991).

In terms of their source rock potential, the samples present fair to excellent hydrocarbon generation potential as far as the TOC values are concerned. Further Rock-Eval analysis is required for a thorough source rock appraisal. The studied formation present three main different types of source rocks: A limited potential for the lower part where TOC values range close to the threshold of $0.5 \%$. An excellent potential for the middle part, where TOC content is in general over $5 \%$. The upper part presents a fair potential with TOC content over $4 \%$. 


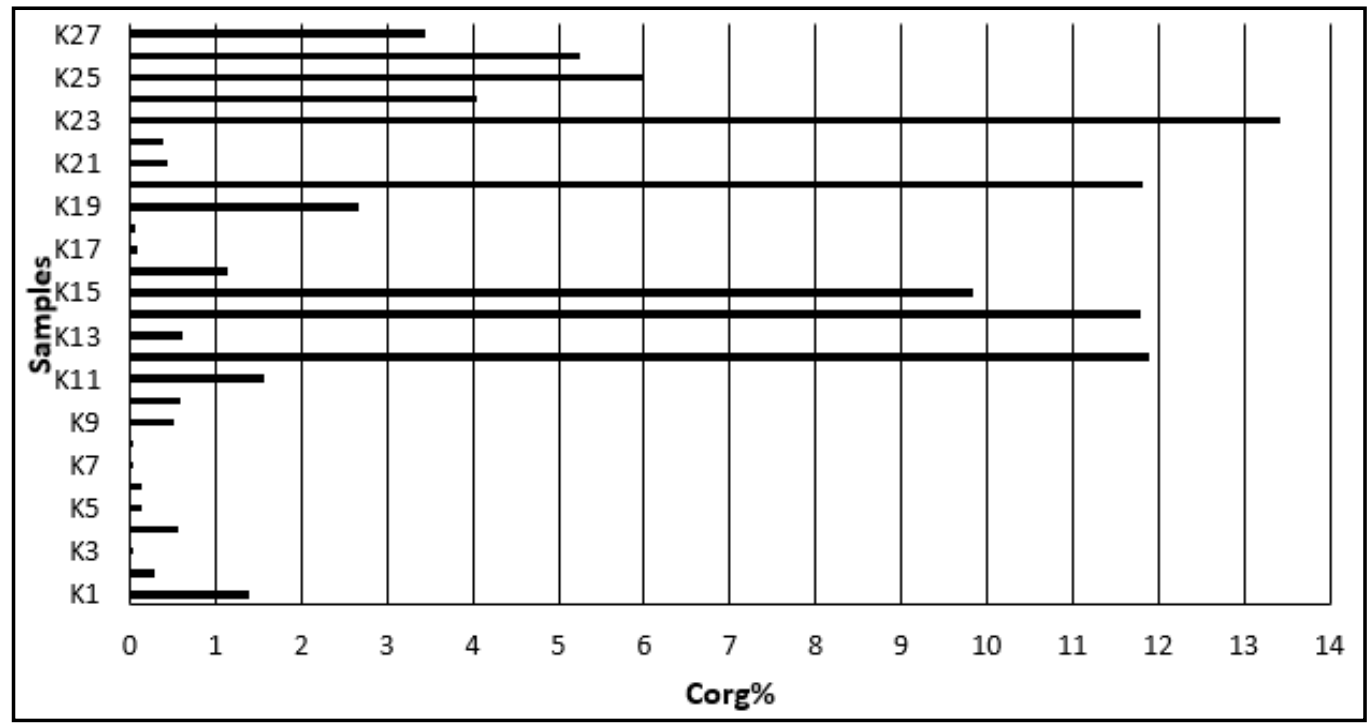

Figure 4 - TOC content in studied samples.

\section{2. $\mathrm{CaCO}_{3}$ measurements}

For the determination of calcium carbonate $\left(\mathrm{CaCO}_{3}\right)$ content, the method for decomposition of the $\mathrm{CaCO}_{3}$ with $\mathrm{CH}_{3} \mathrm{COOH}$ (acetic acid) is used (Varnavas, 1979). This method relies on the full decomposition of calcium carbonate $\left(\mathrm{CaCO}_{3}\right)$ with acetic acid $\left(\mathrm{CH}_{3} \mathrm{COOH}\right)$, to form a soluble salt of calcium acetate $\left(\left(\mathrm{CH}_{3} \mathrm{COO}\right)_{2} \mathrm{Ca}\right)$ and escape the produced carbon dioxide $\left(\mathrm{CO}_{2}\right)$.

Laboratory results showed that the samples are moderately enriched in calcium carbonate (Fig. 5) averaging approx. $12.00 \%$ and ranging between $23.32 \%$ (K9) and $4.13 \%$ (K27).

\section{3. $\mathrm{CaCO}_{3}$ - TOC correlations}

Certain physical and geochemical characteristics control the relation between TOC and $\mathrm{CaCO}_{3}$ in sediments and several studies have correlated these two parameters in Greek sites (see ref. in Nioti et al., 2013). The decomposition of TOC in deeper parts produces $\mathrm{CO}_{2}$ which in turn accelerates dissolution of $\mathrm{CaCO}_{3}$ and this process is often portrayed with proportional values of the variables. Positive relations can also be observed where $\mathrm{CaCO}_{3}$ productivity is present or by other controlling factors such as sedimentation and/or burial rates. $\mathrm{A} \mathrm{CaCO}_{3} / \mathrm{TOC}_{\text {plot }}$ was constructed to investigate such correlations (Fig. 6).

A general upward trend of synchronous decrease was observed, suggests a change to more oxidizing conditions following the lignite production. Furthermore, lower $\mathrm{CaCO}_{3}$ values with synchronous increase with TOC content suggest increase in general productivity. 


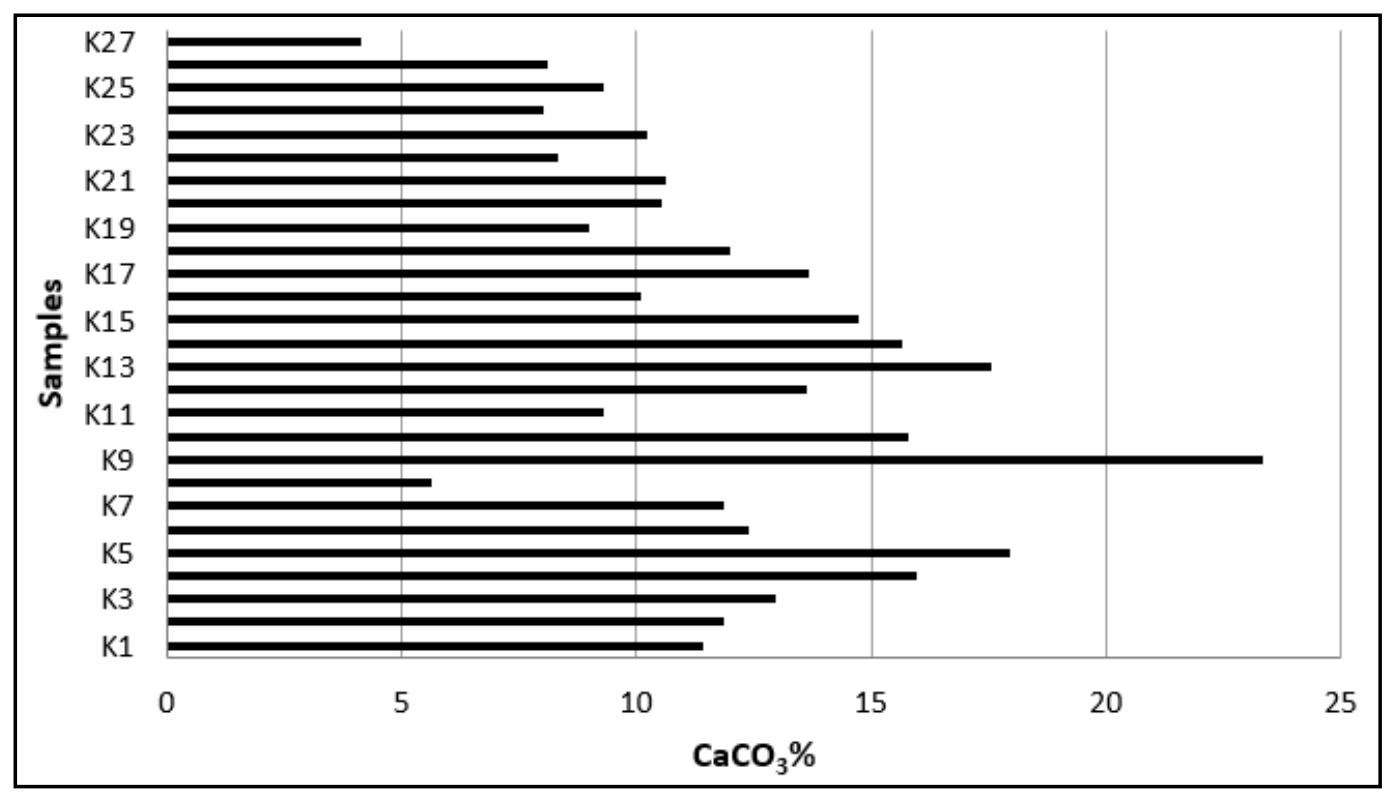

Figure 5 - $\mathrm{CaCO}_{3}$ content in studied samples.

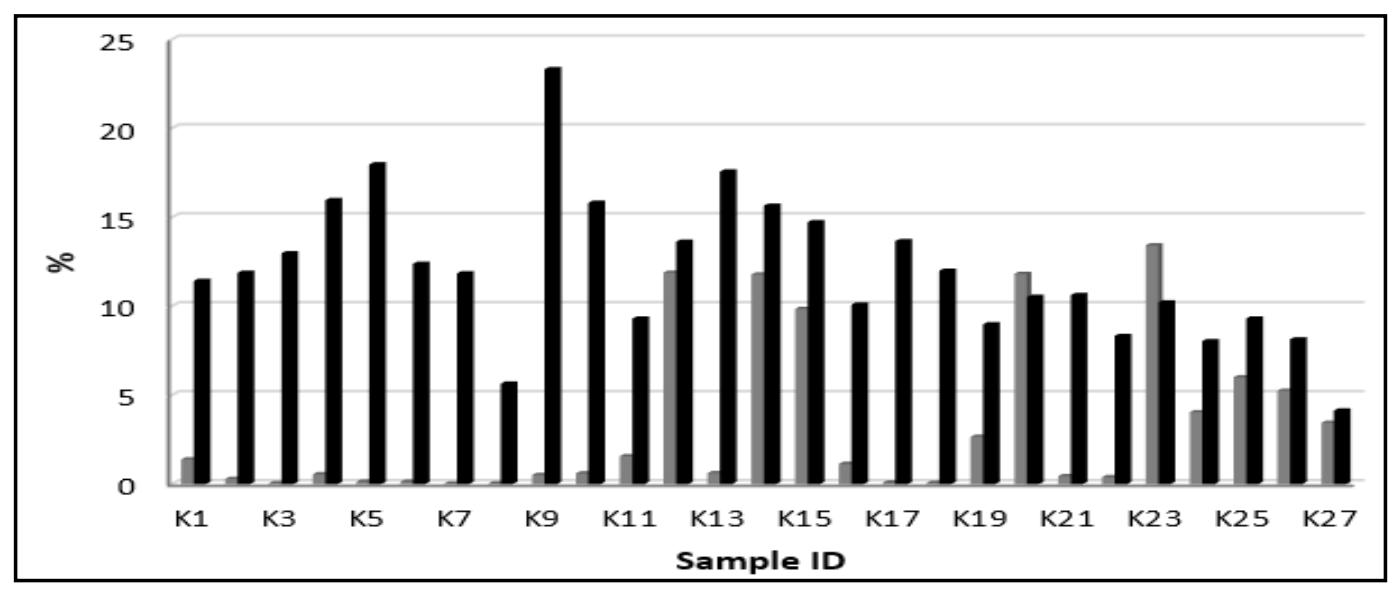

Figure 6 - TOC (gray)-CaCO3 (black) correlation plot.

\subsection{Grain size analysis and micropaleontological analysis}

The grain size analysis, aims to determine the lithology and grain size parameters to describe the particle size distribution of sediments. The method of sieve analysis for the sediments $>63 \mathrm{~mm}$, and the method of the pipette analysis for the sediments $<63 \mathrm{~mm}$ were used. Results of grain-size analysis were constructed as cumulative grading curves and the lithologic character of the sediments was according to the classification of Folk and Ward (1957), whereas the statistical parameters were also calculated (median Md, mean average Mz, standard deviation $\sigma \mathrm{i}$, asymmetry SK1 and curvature $\mathrm{KG})$.

According to the classification by Folk, as derived from the grain analysis results, the samples generally vary from silty to muddy sands. The constructed Passega (1964) plot presents that the samples were transferred primarily as a homogeneous suspension. Samples K10 and K11 were 
transferred by rolling and swinging while remaining as a homogeneous suspension. The $\sigma 1 / \mathrm{Md}$ plot (Stewart, 1958) indicates slow deposition of sediments in calm water. The $\sigma 1 /$ Sk1 plot (Valia and Cameron, 1979) indicates a general shallow environment, with the exception of some samples which seem to have deposited in deeper waters.

In regard of micro-fossils investigation, the vast majority of the samples were barren, while plant residues were observed throughout, especially in the lignite-bearing samples. In sample K10 a fish bone part was identified. Micro-fossils were only present in sample K9, where two ostracod valves were collected. These two fossils were identified in the family Cyprididae and the genus Herpetocypris. Although this primary investigation may only hint guidelines for further study, the presence of plant residues and the Herpetocypris sp. valves indicate a low salinity and/or lacustrine depositional environment, which correspond with both previous studies (Benda and Steffens, 1981) and sedimentological observations.

\section{Discussion}

Studied deposits are of Miocene age, the same age with the source of the neighboring known Prinos oilfield. So, since the area feeds the deeper and subsiding Thermaikos gulf, the high TOC values provide important source of organic matter in regard of hydrocarbon production. The thick deposits in the central area of the Thermaikos gulf could offer the maturity of the Miocene source. Hydrocarbons could have migrated through bedding or faults and the more unconsolidated sand beds and potentially trapped by either upper Miocene (Messinian) evaporites or other structural and/or stratigraphic traps. Further research, including Rock-Eval pyrolysis for the selected samples and comparative studies in Thermaikos' sediments might lead to constructing a depositional model for the basin.

\section{Conclusions}

The Moschopotamos area is situated at the western margins of the Axios-Thermaikos basin, and represents the terrestrial to deltaic part of the basin, sourced both from north and west, feeding the deeper parts in the Thermaikos gulf.

Studied deposits generally vary from silty to muddy sands, deposited mostly as homogeneous suspension, with slow deposition processes in a shallow environment with calm/stagnant water.

Combined earlier studies with results of this study, from the lignite-bearing section of the Neogene accumulation, an early Miocene deposition in a lacustrine environment are indicated.

TOC results presented a high range averaging approx. $3.26 \%$, ranging from $0.07 \%$ up to $13.42 \%$, whereas the calcium carbonate $\left(\mathrm{CaCO}_{3}\right)$ content has an average of $12 \%$, ranging from $4.13 \%$ up to $23.32 \%$. The studied sediments present three main different types of source rocks: A limited potential for the lower part, where TOC values range close to the threshold of $0.5 \%$. An excellent potential for the middle part, where TOC content is in general over $5 \%$ and fair potential for the upper part, with TOC content over $4 \%$.

The correlation between $\mathrm{TOC}$ and $\mathrm{CaCO}_{3}$ indicate a change to more oxidizing conditions following the lignite production, whereas the lower $\mathrm{CaCO}_{3}$ values with synchronous increase with TOC content suggest increase in general productivity.

\section{References}

Benda, L. and Steffens, P., 1981. Aufbauy and Alter des Neogens von Katerini, Griechenland, Geologische Jahrbuch, B42, 93-103.

Brooks, M. and Ferentinos, G., 1980. Structure and evolution of the sporadhes basin of the North Aegean Trough, Northern Aegean sea, Tectonophysics, 68, 15-30. 
Faugeres, L. and Robert, Ch., 1976. Etude sedimentologique et mineralogique de duex forages du golf Thermaique (mer Egee), Geology of Meditteranean, 4, 209-218.

Folk, R.L., 1968. Petrology of Sedimentary Rocks, Hemphill Publishing Co, Austin, Texas, 170 pp.

Folk, R.L. and Ward, W.C., 1957. Brazos river bar: a study of significante of grain size parameters, J. Sediment. Petrol., 27, 3-26.

Gaudette, H.E., Flight, E.R., Toner, L. and Folger, D.W., 1974. An inexpensive titration method for the determination of organic carbon in recent sediments, Journal of Sedimentary Petrology, 44, 249-253.

Kotis, T. and Papanikolaou, K., 1999. Depositional environment of lignite bearing sediments in the Neogene basin of Moschopotamos Pieria, Greece, Bulletin Geological Society Greece, 33, 17-28.

Kalkreuth, W., Kotis, T., Papanicolaou, C. and Kokkinakis, P., 1991. The geology of a Miocene lignite profile at Meliadi mine, Katerini, Greece, International Journal of Coal Geology, 17, 51-67.

Lykousis, V., Roussakis, G., Alexandri, M., Pavlakis, P. and Papoulia, I., 2002. Sliding and regional slope stability in active margins: North Aegean Trough (Mediterranean), Marine Geology, 156, 281-298.

Nioti, D., Maravelis, A., Tserolas, P. and Zelilidis, A., 2013. TOC and $\mathrm{CaCO}_{3}$ content in oligocene shelf deposits on lemnos island and their relation with depositional conditions, Bulletin of the Geological Society of Greece, XLVII, Proceedings of the $13^{\text {th }}$ International Congress, Chania, Sept. 2013.

Maravelis, A. and Zelilidis, A., 2013. Discussion on: 'Unraveling the provenance of EoceneOligocene sandstones of the Thrace Basin, North-east Greece', Sedimentology, 60, 860-864.

Maravelis, A.G., Pantopoulos, G., Tserolas, P. and Zelildis, A., 2015. Accretionary prism-forearc interactions as reflected in the sedimentary fill of southern Thrace Basin (Lemnos island, NE Greece), International Journal of Earth Sciences, 104, 1039-1060.

Mountrakis, D., 2006. Tertiary and Quartenary tectonics of Greece, In: Dilek, Y. and Pavlides, S., eds., Postcollisonal tectonics and magmatism in the Mediterranean region and Asia, Geological Society of America, Special Paper 409, 125-136.

Passega, R., 1964. Grain size representation by C-M patterns as a geologic tool, Jour. Sed. Petrol., Tulsa Okla, 34(4), 830-847.

Stewart, H.B.Jr., 1958. Sedimentary reflections of depositional environments in San Miguel Lagoon, Baja California, Mexico, Am. Assoc. Petr. Geol. Bull., 42, 2567-2618.

Valia, H.S. and Cameron, B., 1977. Skewness as a Paleoenvironmental indicator, Jour. Sed. Petr., 47, 2, 784-793.

Varnavas, S.P., 1979. Geochemistry of sediments from the eastern Pacific, Ph. D. Thesis University London, 431 pp. 